\title{
AFINAL, QUANTO CUSTOU A COPA DO MUNDO PARA A SOCIEDADE BRASILEIRA?
}

Coluna publicada em 3.6.2014: <http://www.conjur.com.br/2014-jun-03/ afinal-quanto-custou-copa-mundo-sociedade-brasileira $>$

É “a pergunta que não quer calar” este ano. E que, muito provavelmente, já adianto, ficará sem resposta. O Direito Financeiro e as Finanças Públicas dificilmente poderão satisfazer a curiosidade da sociedade brasileira, até porque se trata de uma questão muito mais complexa do que parece à primeira vista.

A começar pelo fato de que os gastos não se resumem à construção de estádios, pois abrangem uma complexa infraestrutura de aeroportos, portos, metrôs, rodovias, rede hoteleira, mobilidade urbana, um sem-número de serviços públicos de segurança, logística e tantos outros que é difícil nominar sem esquecer algum.

Mais. É uma despesa distribuída entre o poder público e os particulares, em relações nem sempre claras e simples de serem contabilizadas, explicáveis pela multiplicidade e diversidade de meios e instrumentos pelos quais se viabilizam.

$\mathrm{E}$, nesse caso, não nos esqueçamos, a relação com o poder público abrange todas as esferas de governo, pois a Copa do Mundo envolveu União, estados e municípios, o que é um grande fator complicador para mensurar, avaliar e tornar transparentes essas despesas. "Vivemos um inferno, sobretudo porque no Brasil tem três níveis políticos", reclamou Jérôme Valcke. ${ }^{1}$ A frase do Secretário-Geral da FIFA, responsável por acompanhar as obras de infraestrutura para a Copa do Mundo no Brasil, traduz em poucas palavras as dificuldades enfrentadas pela administração pública em um país de dimensões continentais como o nosso, cuja organização adota o sistema federativo, e com clara separação de poderes.

Folha de S.Paulo, 11 de maio de 2014, p. C8. 
Desde o início, falou-se que a Copa do Mundo seria realizada com recursos privados. Afirmação que, como já se suspeitava, se mostrou inverídica, pois, ainda que muitas ações tenham sido realizadas pelo setor privado, várias delas acabaram sendo de responsabilidade da administração pública, sem contar as inúmeras situações em que a despesa "privada" foi, em boa parte, composta por recursos públicos, como veremos ao longo deste texto.

Neste ponto, é importante ressaltar que nem toda despesa pública consta dos orçamentos públicos. É cada vez mais frequente o fenômeno da "desorçamentação" ou das off-budget expenditures, que compreendem uma série de operações financeiras que "escapam" da lei orçamentária anual, mitigando a transparência e dificultando o controle. ${ }^{2}$ E elas estão bem presentes em nossa Copa do Mundo.

Especial atenção merecem os gastos tributários (ou tax expenditures, para usar a expressão consagrada por Stanley Surrey), financiamentos (diretos ou garantidos pelo poder público) e gastos realizados por empresas estatais, além de outros que não são apuráveis pela análise dos orçamentos públicos.

Os chamados "gastos tributários" abrangem inúmeras formas de benefícios fiscais, tais como isenções, diferimentos, facilidades tributárias de diversas naturezas que, na prática, resultam em redução de receitas pelo não pagamento de tributos e devem ser interpretados como verdadeiras despesas públicas. Ainda que os orçamentos devam conter demonstrativo que os contemplem $\left(\mathrm{CF}\right.$, art. 165 , $\$ 6^{\circ}$, e Lei de Responsabilidade Fiscal, art. 50, II), nem todos os entes da federação cumprem o que foi determinado e outros o fazem de forma pouco específica, impedindo que se tenha o exato conhecimento de quanto esses valores efetivamente representam para os cofres públicos. Foram largamente utilizados por todos os entes da federação, e não há dados suficientes e claros que permitam precisar o valor exato. ${ }^{3}$

Operações financeiras envolvendo o poder público, quer diretamente pela concessão de empréstimos, quer na forma de garantias, podem onerar o tesouro, e não há como mensurá-las com precisão, deixando uma interrogação sobre quanto custaram muitas das ações governamentais importantes para completar toda a infraestrutura necessária ao evento. ${ }^{4}$

2 Veja-se, a respeito do tema, o recente trabalho Regime jurídico da despesa pública no Brasil, de Emerson Gomes (Tese de doutorado em Direito Financeiro - USP, 2014, p. 30 e seguintes).

3 Há detalhado relatório de levantamento do rol de renúncias de receitas tributárias, financeiras e creditícias relacionadas ao evento Copa 2014, produzido pelo Tribunal de Contas da União - TCU (TC 034.303/2011-1, Acórdão 3.249/2012, Plenário, rel. Min. Valmir Campelo, em 28 de novembro de 2012).

4 Vide, por exemplo, o ProCopa Arenas, linha de financiamento do BNDES destinada a "apoio a projetos de construção e reforma das arenas que receberão os jogos da Copa do Mundo de 2014 e de urbanização de seu entorno" (Resolução 1.888/2010/BNDES). 
De outro lado, grandes obras, apesar de terem sido impulsionadas pela realização da Copa do Mundo, foram e são necessárias para nossa sociedade e não é razoável considerá-las como "gastos da Copa", pois continuarão sendo úteis independentemente do evento. Vide os principais aeroportos do país, já há muito defasados em relação às nossas necessidades, e as obras neles realizadas são o mínimo que se espera para que cumpram suas funções de forma eficiente. Por oportuno, registre-se que nisto a Copa do Mundo foi importante: chamou a atenção para as deficiências na infraestrutura do país, extremamente defasada, não só nos aeroportos, mas em muitas áreas essenciais para o desenvolvimento.

A multiplicidade de entes federados, todos autônomos e com seu próprio orçamento, e a necessidade de participação conjunta deles em muitas das ações governamentais voltadas à realização do evento, em um exemplo de cooperação federativa que caracteriza o Estado brasileiro, descentralizam a contabilização dos custos. Embora alguns entes da federação tenham criado programas orçamentários específicos, ${ }^{5}$ outros diluíram as despesas em dotações de programas diversos, impedindo que se possa saber com clareza e transparência os valores aplicados.

Como se pode ver, a questão é complexa e não é fácil computar os gastos públicos com a Copa do Mundo.

De qualquer forma, alguns valores são interessantes mencionar, e permitem dar uma dimensão aproximada e parcial deles, afastando alguns mitos que foram criados.

Informações recém-divulgadas dão conta de que os custos da Copa do Mundo somam R \$25,8 bilhóes, o que corresponde a 9\% das despesas públicas anuais em educação, ${ }^{6}$ e equivale às despesas previstas no orçamento do Estado de São Paulo para a área da segurança pública neste ano de 2014, como mencionado nas páginas 65-68, Financiamento da segurança pública precisa de atenção, nesta edição.

Ainda que devam ser relativizados, dadas as considerações feitas ao longo de tudo o que foi dito anteriormente, há que se reconhecer serem valores de dimensões menores do que se imaginava, ao pensar que com esses recursos seria possível resolver nossos graves problemas, como saúde, educação e segurança pública, serviços públicos prestados pelo Estado que asseguram direitos fundamentais do cidadão.

Além de serem muito caros, esses serviços utilizam-se essencialmente de despesas de custeio, que são permanentes e praticamente incomprimíveis, diferentemente

5 Como exemplificam André Carvalho e Leonardo Dias. Panorama dos investimentos públicos e privados para a Copa do Mundo de 2014 e Jogos Olímpicos de 2016. Revista de Direito Bancário e do Mercado de Capitais, n. 48, 2010, p. 86-87.

6 Custo da Copa equivale a um mês de gastos com educação. Folha de S.Paulo, 23 de maio de 2014, p. A-8. 
do que foi gasto com a Copa do Mundo, cujas obras de infraestrutura, por serem basicamente despesas de capital, não vão onerar com a mesma intensidade, de forma permanente, os cofres públicos.

Apesar disso, não podemos, de forma alguma, concluir que a Copa do Mundo nos custou pouco, pelo contrário. Nela há muito dinheiro público e não se pode dizer que tenha sido bem gasto, pois, ainda que não fosse suficiente para suprir as falhas nesses serviços públicos cuja melhora é reivindicação permanente da população, é de se pensar se não teria sido mais conveniente destinar os recursos para essa finalidade. Sem esquecer do alerta já várias vezes repetido: o importante é gastar bem, e não gastar mais.

Enfim, vê-se que este assunto é interessante, importante e muito instigante e merece uma análise mais detalhada. Mas é hora de parar de falar sobre Direito Financeiro e começar a torcer. Semana que vem nossa seleção entra em campo. Infelizmente o Direito Financeiro, nesta Copa, não vai levar a taça. Nem uma medalhinha. Mas, seguramente, ganharemos experiência no assunto, extraindo lições úteis para o futuro.

Agora que a conta já foi e está sendo paga, chega de chorar sobre o leite derramado. Pode ter custado caro, mas nosso futebol vai fazer valer cada centavo e nos trazer essa taça!

7 Coluna Responsabilidade orçamentária precisa de melhorias, nesta edição, p. 259-261. 